\title{
Prilog proučavanju razvoja i značenja ruralnog turizma u Općini Šestanovac
}

\author{
Nediljko Ralica \\ Statim d.o.o., Split, Hrvatska \\ e-mail:nenor14@gmail.com
}

\author{
Ante Blaće \\ Sveučilište u Zadru, Odjel za geografiju, Hrvatska \\ e-mail:anblace@unizd.hr
}

SAŽETAK U radu istražuju se mogućnosti razvoja turizma u Općini Šestanovac, ruralnom području omiškog dijela Dalmatinske zagore. Na temelju statističkih podataka i terenskog rada analizirani su elementi prirodne i kulturne baštine koji se mogu vrednovati u turizmu i trenutačno stanje turizma u općini. Provedeno je i anketno istraživanje da bi se saznalo mišljenje lokalnog stanovništva o različitim aspektima razvoja turizma u Općini Šestanovac. Dobiveni rezultati ukazuju na to da broj turista koji dolaze u Šestanovac nije velik, ali da kontinuirano raste. Zasad je najrazvijeniji seoski turizam na obiteljskim poljoprivrednim gospodarstvima i u kućama za odmor te pustolovni turizam, koji se odvija u kanjonu rijeke Cetine, na planini Biokovo i na biciklističkim stazama. Materijalna i nematerijalna kulturna baština još se dovoljno ne vrednuje i trebala bi biti uključenija u turističku ponudu. Lokalno stanovništvo smatra da turizam može imati veliku ulogu u budućem gospodarskom razvoju općine i općenito pozitivno percipira sve što je povezano s turizmom u Šestanovcu.

Ključne riječi: turizam, Općina Šestanovac, seoski turizam, pustolovni turizam, prirodna i kulturna baština. 


\section{Uvod}

Većina ruralnog prostora Hrvatske obilježena je depopulacijom i deagrarizacijom (Lukić, 2012.). Iseljavanje (posebno mlađeg stanovništva) (Nejašmić i Štambuk, 2003.:479) posljedica je, između ostalog, i nepovoljne gospodarske slike - malog broja radnih mjesta, nedostatnih prihoda i niske kvalitete života (Rajković Iveta i Horvatin, 2017.:268). Usitnjeni posjedi, zastarjela i nedostatna proizvodnja i uglavnom niske cijene proizvoda obilježja su poljoprivredne proizvodnje (Tomić, 2014.:130-131). S obzirom na činjenicu da se u Republici Hrvatskoj trenutačno ostvaruje oko $20 \%$ bruto društvenog dohotka u turizmu (Ministarstvo turizma, 2019.:43), nameće se pitanje je li turizam čimbenik koji bi u ruralnim prostorima mogao ublažiti negativne procese. Budući da je Primorska Hrvatska, odnosno uski obalni i otočni pojas tijekom ljetne sezone opterećen velikim brojem gostiju i ima odlike masovnog turizma, u zaobalnim ruralnim područjima trebaju se razvijati oni oblici turizma koji bi doprinijeli gospodarskom razvoju, ali i očuvali okoliš te elemente prirodne i kulturne baštine.

Ruralni prostori čine oko 90 \% površine Hrvatske, a u njima živi oko $45 \%$ ukupnog broja stanovnika (Lukić, 2014.:362). Istovremeno taj veliki prostor ostvaruje samo oko $3 \%$ ukupnih turističkih noćenja (Košak i Lugomer, 2015.:142). To je višestruko manje od zapadnoeuropskih zemalja koje ostvaruju 10 - $20 \%$ noćenja u ruralnim područjima (Demonja i Ružić, 2010.:70). S obzirom na raznolikost i bogatstvo prirodne i društvene osnove, u ruralnim prostorima Hrvatske mogli bi se razvijati različiti oblici turizma (seoski/agroturizam, sportski, pustolovni, gastronomski, ekoturizam i dr.) (Ružić i Demonja, 2013.; Demonja, 2014.), objedinjeni pod zajedničkim nazivnikom ruralnog turizma.

Ruralni turizam oblik je turizma koji se u najširem smislu odnosi na turizam na ruralnom području, a uključuje sve aktivnosti koje se provode na tom području (Demonja i Ružić, 2010.:12). Izostanak buke, očuvan okoliš, komuniciranje s domaćim stanovništvom, domaća hrana, fizička aktivnost te upoznavanje i sudjelovanje u seoskim poslovima najvažnija su obilježja ruralnog turizma. U okviru ruralnog turizma jedan je od najččšcih oblika seoski turizam. On obuhvaća različite djelatnosti koje spajaju turizam i poljoprivredu, a odvijaju se na obiteljskim poljoprivrednim gospodarstvima (Demonja, 2014.:73). Za početak razvoja seoskog turizma u Hrvatskoj može se okvirno uzeti 1998., kad je registrirano prvih 30-ak seoskih gospodarstava koja se bave turizmom (Demonja, 2014.:75). Naime, turistička seoska obiteljska gospodarstva (TSOG) čine okosnicu razvoja seoskog turizma (Svržnjak i sur., 2014). Donošenje strategija i planova o razvoju ruralnog prostora Hrvatske i ruralnom turizmu (Kušen, 2003.:30), pristupanje Europskoj uniji i mogućnost korištenja financijskim poticajima potaknuli su intenzivniji porast gospodarstava, pa ih je 2017. zabilježeno 447 (Grgić i sur., 2017.:99). Istarska i Dubrovačko-neretvanska županija prednjače u broju seoskih gospodarstava u Primorskoj, a Zagrebačka i Osječko-baranjska županija u Panonsko-peripanonskoj Hrvatskoj (Košak i Lugomer, 2015.:150). Prema rezulta- 
tima istraživanjima Instituta za turizam (Grgić i sur., 2017.:103), seoski bi turizam u Hrvatskoj 2020. trebao biti poznat i komercijalan proizvod koji privlači domaće i strane goste zbog izvornog ozračja i iskustva prilagođenog svakom pojedinom gostu.

Općina Šestanovac ruralni je prostor omiškog dijela Dalmatinske zagore. Cilj je rada istražiti koje su mogućnosti razvoja ruralnog turizma u Općini Šestanovac s obzirom na elemente prirodne i kulture baštine i stavove lokalnog stanovništva. O Šestanovcu dosad gotovo da i nije bilo znanstvenih istraživanja. Tek su u nekoliko radova (Carević, 2011.; Nejašmić, 2015.; Malenica, 2016.) razmotrene demografske, gospodarske i razvojne značajke prostora Omiške zagore, pa tako i Šestanovca. Autori su naglasili negativne razvojne procese koji obilježavaju taj kraj. O turizmu Zagore pisano je uglavnom za potrebe ocjenskih (završnih i diplomskih) radova. U njima su autori (Vojnović, 2011.; Grcić, 2012.; Pastuović, 2016.; Todorić, 2017.; Ćubelić, 2018.; Božić Juras 2019.) zaključili da seoski turizam ima najveće razvojne mogućnosti, kao i to da je taj potencijal ipak više iskorišten na području Imotske krajine i Dugopolja, dok ostali dijelovi Dalmatinske zagore zasad zaostaju.

Polazišne su hipoteze sljedeće:

1. Najpovoljnije uvjete razvoja u Općini Šestanovac ima seoski turizam.

2. Lokalno stanovništvo smatra da turizam može značajno pridonijeti razvoju Općine Šestanovac.

3. Mlađi naraštaji ne bi emigrirali iz općine ako bi im bavljenje turizmom omogućilo egzistenciju.

\section{Područje istraživanja}

Općina Šestanovac jedinica je lokalne samouprave zaobalnog dijela Splitsko-dalmatinske županije (Slika 1). Dio je Omiške zagore i zauzima površinu od $88,9 \mathrm{~km}^{2}$. U sastavu općine nalazi se pet naselja: Kreševo, Katuni, Žeževica, Grabovac te Šestanovac kao upravno središte. Prirodnogeografske granice općine čine brdo Vitrenik na sjeveru, Sidoč na istoku, planina Biokovo na jugoistoku, kanjon rijeke Cetine na zapadu te brdo Kreševnica na sjeverozapadu. Od obale udaljena je 15-ak kilometara, a prometno je dobro povezana jer njome prolazi dionica autoceste Zagreb - Ploče izgrađena 2007. 
Slika 1.

Geografski položaj Općine Šestanovac

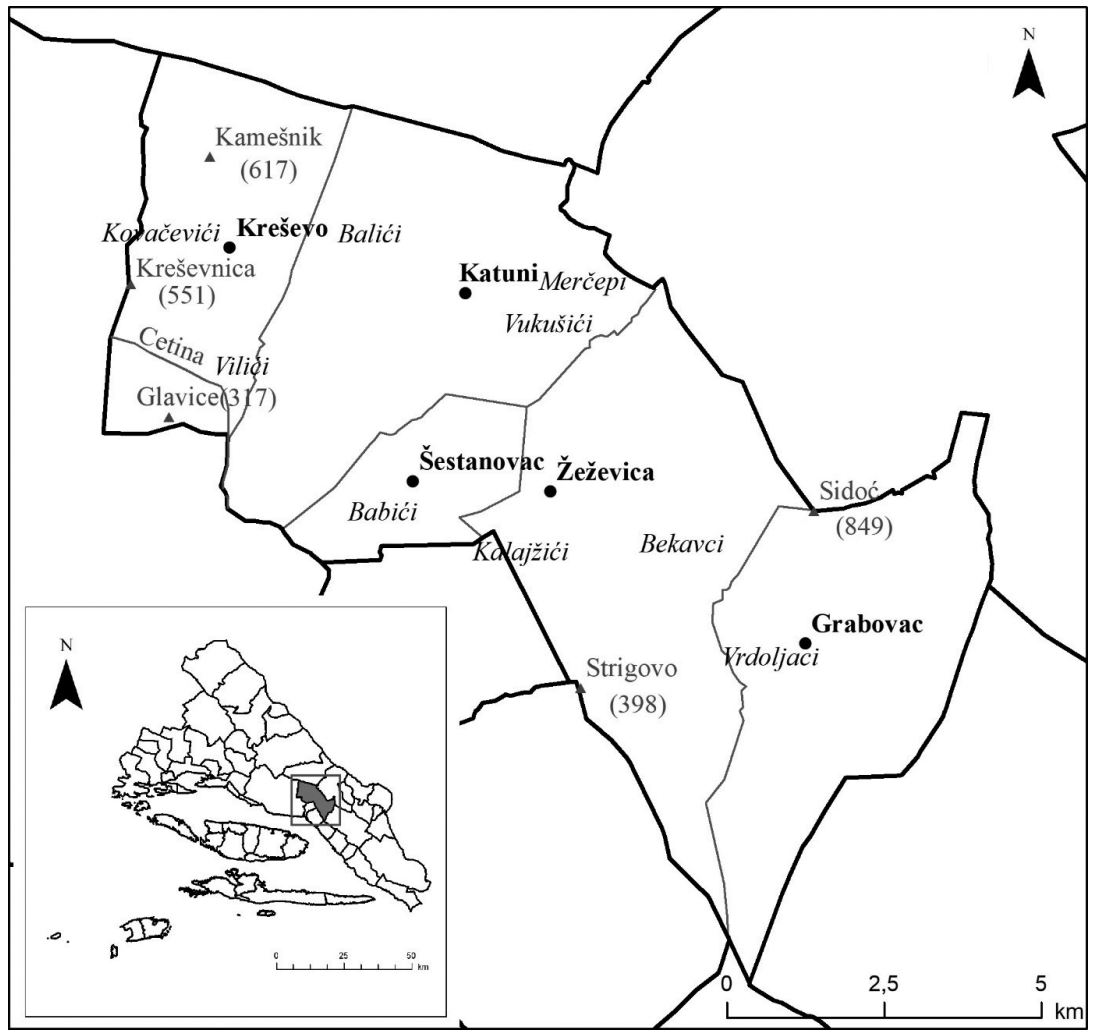

Izvor: izrađeno na temelju: Sredšnji registar prostornih jedinica RH, 2016.

Najveći dio prostora Općine Šestanovac građen je od vapnenaca kredne starosti. S obzirom na takvu geološku građu prevladavaju krški reljefni oblici poput zaravni, draga, jaruga, dolaca i dr. Klima je umjereno topla vlažna s vrućim ljetom (Cfa prema Köppenu) (Šegota i Filipčić, 2003.). Prosječna višegodišnja količina padalina iznosi oko $1300 \mathrm{~mm}$, a dva su mjeseca toplija od $22^{\circ} \mathrm{C}$ (srpanj i kolovoz) (Državni hidrometeorološki zavod, 2017.).

Prema posljednjem popisu stanovnika iz 2011. godine, u Općini Šestanovac živjelo je 1958 stanovnika, što je najmanji broj stanovnika otkad se provode službeni popisi (Slika 2). Primjetan je pad broja stanovnika od 1953., što je bilo potaknuto industrijalizacijom na obali, a izraženiji pad vidljiv je od 1971., nekoliko godina nakon gradnje Jadranske turističke ceste na širem splitskom području i jačanja turizma. Dio stanovnika otišao je u inozemstvo (SR Njemačku) u potrazi za poslom. Prema procjeni iz 2018., u općini je živjelo još manje, 1716 stanovnika (Državni zavod za statistiku, 2019.). 
Slika 2.

Kretanje broja stanovnika Općine Šestanovac od 1857. do 2011. godine

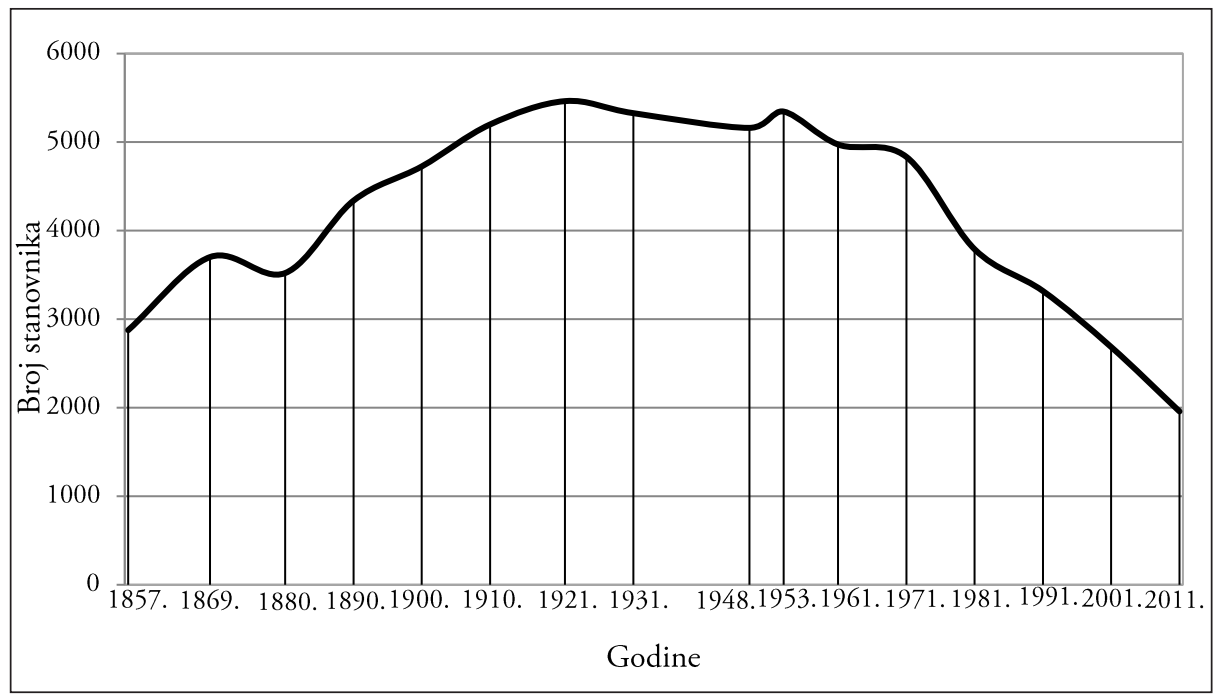

Izvor: izrađeno na temelju: DZS, 2020.

Opća gospodarska slika Općine Šestanovac nije povoljna. Prosječna stopa nezaposlenosti od 2014. do 2016. iznosila je gotovo $21 \%$, što je i do tri puta više nego tadašnja prosječna stopa nezaposlenosti u Hrvatskoj (Ministarstvo regionalnog razvoja i fondova Europske unije, 2018.). Popisom stanovnika iz 2011. utvrđeno je da je u cijeloj općini 32 ljudi bilo aktivno u djelatnostima pružanja smještaja te pripreme i posluživanja hrane, što je činilo $7 \%$ ukupno aktivnog stanovništva (DZS, 2011.). Dodatan uvid u opću gospodarsku i demografsku razvijenost na razini jedinica lokalne samouprave pruža indeks razvijenosti, kompozitni pokazatelj od pet varijabli. Prema posljednjem izračunu za razdoblje 2014. - 2016., Općina Šestanovac s vrijednošću indeksa od 94,138 nalazi se na 447. mjestu od 556 općina i gradova u Hrvatskoj (MRRFEU, 2018.). Time je kategorizirana kao ispodprosječno razvijena općina i prostor koji ima pravo na financijsku potporu. Prema tipologijama ruralnih prostora Hrvatske (Lukić, 2012., Lukić, Radeljak Kaufmann, Pejnović, 2016.) i scenarijima razvoja Dalmacije (Radeljak Kaufmann, 2016.), Općina Šestanovac ubraja se u područja kriznih demografskih obilježja i ograničenog gospodarskog razvoja.

\section{Materijali i metode}

U istraživanju korišteno je nekoliko metoda. Postojeća literatura o različitim aspektima turizma istražena je metodama analize i dedukcije. Pokazatelji turističkog prometa (dolasci, noćenja) dobiveni su uvidom u podatke Državnog zavoda za statistiku i Turističke zajednica Grada Omiša i tablično obrađeni. Podaci Ministarstva kulture 
Republike Hrvatske, Nature 2000 i terenskog istraživanja korišteni su za izradu karte prirodne i kulturne baštine Općine Šestanovac u GIS-programu ArcMap 10.1. (ESRI, 2012.).

Da bi se ispitali stavovi lokalnog stanovništva o mogućem turističkim razvoju općine, provedeno je anketno istraživanje u listopadu 2017. Anketa je bila anonimna, a pitanja (ukupno 28) bila su koncipirana od općih (pet pitanja) prema posebnima (23 pitanja). Najprije su se od ispitanika tražili opći podaci (spol, dob, obrazovanje, ekonomska aktivnost, mjesto prebivališta), a potom su uslijedila pitanja koja su se odnosila na turizam (o trenutačnom stanju turizma, o mogućem budućem razvoju, pozitivnim i negativnim aspektima razvoja turizma na području općine itd.). U pitanjima o stavovima stanovništva korištena je Likertova ljestvica od pet stupnjeva čije su vrijednosti odgovarale sljedećim izrazima: 1 - uopće se ne slažem, 2 - uglavnom se ne slažem, 3 - niti se slažem niti se ne slažem, 4-uglavnom se slažem, 5- u potpunosti se slažem. Primijenjeno je proporcionalno stratificirano uzorkovanje, odnosno iz svakog naselja općine anketiran je broj ispitanika koji je proporcionalan broju stanovnika naselja u ukupnom stanovništvu općine. Izbor ispitanika u svakom naselju određen je slučajno. U obzir su došli stanovnici stariji od 15 godina i mlađi od 65 godina. Nastojalo se paziti i na omjer dobnih skupina, npr. da udio mladih ispitanika bude oko jedne trećine jer je u općini trećina mladog stanovništva. Anketa je provedena na internetu te pisanim anketnim upitnicima. Mlađe stanovništvo uglavnom je ispunilo anketu na internetu, dok je starije stanovništvo uglavnom ispunjavalo anketni upitnik. Ukupno je 96 osoba sudjelovalo u istraživanju. Na temelju odgovora iz ankete izrađeni su grafikoni i provedene statističke analize metodama hi-kvadrat testa i korelacije korištenjem Statistice 13.3 (TIBCO Software, 2017.), računalnog programa za kvantitativne analize. Prije analize rezultata upitnika proveden je Cronbachov alfa-test pouzdanosti za pitanja s Likertovom skalom.

\section{Rezultati i rasprava}

\subsection{Prirodna i kulturna baština Općine Šestanovac}

Prirodna osnova prostora (geološke i geomorfološke značajke, klima, vode, biljni i životinjski svijet) može imati veliki utjecaj na razvoj turizma (Kušen, 2002.). Na prostoru Općine Šestanovac dva su zaštićena elementa prirodne baštine, kanjon rijeke Cetine i planina Biokovo (Natura 2000, 2019.). Rijeka Cetina protječe prostorom općine u duljini od 5,8 km i taj kanjonski dio toka proglašen je zaštićenim krajobrazom. Kanjon je vizualno privlačan s mnogobrojnim egzokrškim oblicima (kamenicama, škrapama) u njegovoj neposrednoj blizini. Jugoistočni dio općine koji je geomorfološki najraščlanjeniji s visinama do 1500 m zahvaća dio planine Biokovo, koja je proglašena parkom prirode. Jame i spilje na području općine zasad su slabo istražene i nisu turistički vrednovane. 
Opće stanje, odnosno očuvanost okoliša, važan je preduvjet razvoja turizma. Ruralni prostor Šestanovca u cjelini obilježava očuvan okoliš, odnosno čist zrak, odsutnost buke, pitka voda, nezagađeno tlo i bioraznolikost. Međutim, u naseljima postoje i divlja odlagališta otpada čiji broj postupno pada zbog sanacije i uvođenja sustava prikupljanja i razvrstavanja otpada po kućanstvima.

Na području općine postoji dvanaest materijalnih kulturnih dobara koji se nalaze na popisu zaštićene kulturne baštine Republike Hrvatske (Slika 3). To su crkva sv. Roka u Kreševu, arheološka zona Vlake, kip Bogorodice, crkva Uznesenja Blažene Djevice Marije, inventar sakralnih predmeta u crkvi Uznesenja Blažene Djevice Marije i Mandušića kula u Katunima, župna crkva sv. Jurja mučenika, stambeno-gospodarski sklop Bolčić i arheološka zona Trbotor u Žeževici, arheološko nalazište Velika Peć, crkva Porođenja Blažene Djevice Marije (Male Gospe) s grobljem i kapela sv. Ivana Krstitelja u Grabovcu (Ministarstvo kulture, 2020.). Arheološka nalazišta obuhvaćaju rukotvorine od neolitika do kraja srednjeg vijeka, dok su crkve i ostala dobra nastala u razdoblju nakon 17. st., odnosno oslobađanja tog prostora od Osmanlija. Osim navedenih dobara, u općini postoji još tridesetak prapovijesnih gromila, gradina i kapelica koje nisu zaštićene, ali jesu dio materijalne kulturne baštine.

U Općini Šestanovac prisutni su i tradicionalno sagrađeni objekti koji, osim sklopa Bolčić, nisu posebno zaštićeni. Tradicijsko graditeljstvo kao dio kulturne baštine cijele Dalmatinske zagore obilježava razumna uporaba prostora, materijala i radne snage. Objekti i naselja pažljivo su nastajali: pazilo se da budu u zavjetrini, na prisojnoj strani, u blizini plodne zemlje, pokraj putova kojima se dolazilo do oranica (Alaupović Gjeldum, 2007.). Sve stare kuće u Općini Šestanovac građene su od kamena koji je, s obzirom na geološku podlogu, lako dostupan u velikim količinama. Osim stambenih objekata, kamenom se koristilo u gradnji gospodarskih zgrada (staja), crkvi, grobalja, putova, zdenaca i sl. Blokovi od kamena koji su se koristili za gradnju oblikovani su na mjestu vađenja. Za vanjske zidove kuća bili su korišteni pravilno klesani blokovi koji su se nazivali vace, a za unutarnje zidove grublje klesani blokovi (Buble, 2007.). Zidovi takvih kuća imaju debljinu od 60 do $80 \mathrm{~cm}$. Za krovišta korištene su kamene ploče koje su cijepane po svojim slojnim plohama. U Općini Šestanovac postoji veliki broj starih kuća zidanih na takav način. One su danas velikim dijelom napuštene jer je stanovništvo počelo graditi nove kuće od betonskih blokova ili cigli. Turistička je valorizacija tradicionalno sagrađenih kuća moguća, no problem predstavljaju imovinskopravni odnosi, odnosno situacije u kojima jedna kuća ima više vlasnika. 
Slika 3.

Prirodna i kulturna baština i značajniji objekti turističke infrastrukture Općine Šestanovac

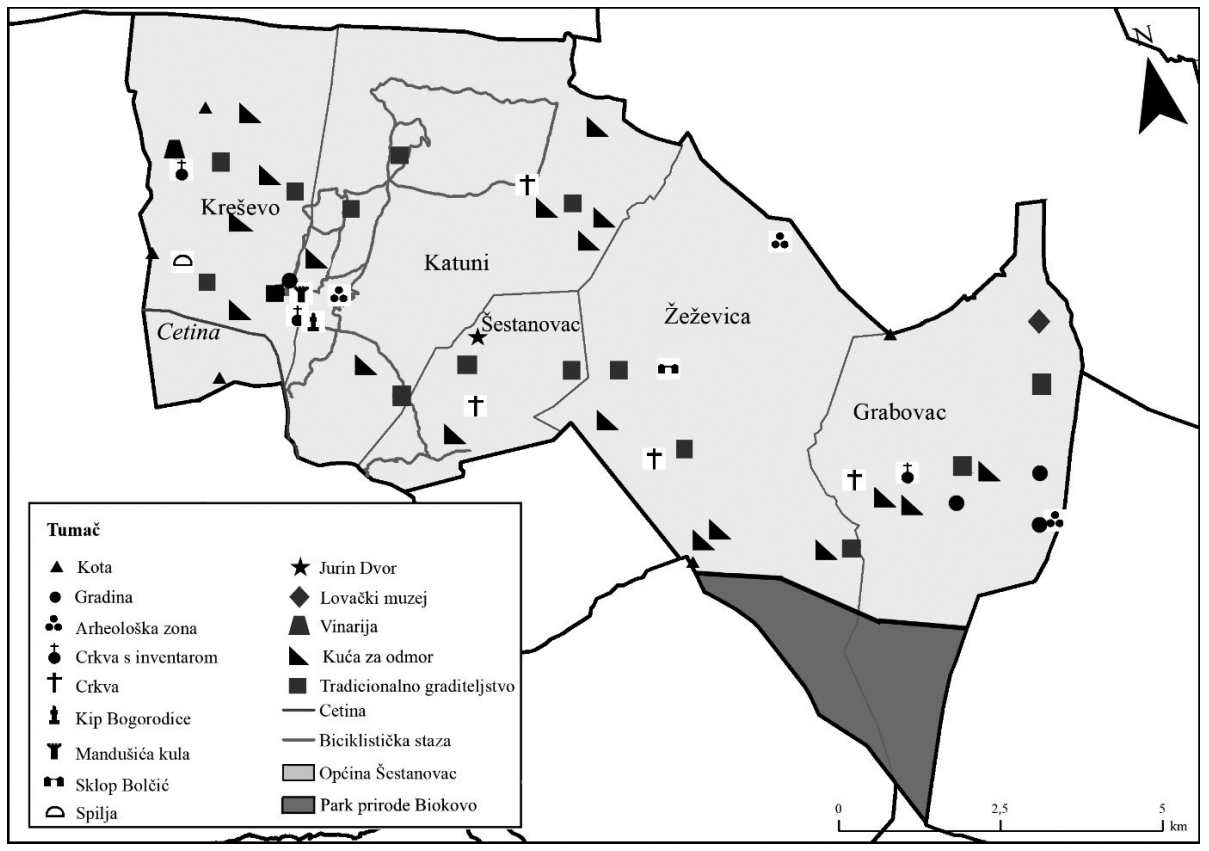

Izvor: izrađeno na temelju: SRPJ RH, 2016., Ministarstvo kulture, 2020., Natura 2000, 2019., Terensko istraživanje, 2019.

Nematerijalna kulturna baština odnosi se na znanja, vještine, predmete, instrumente, predstave, prakse i sl. koje neka zajednica ili pojedinci posjeduju. Ona utječe na razvoj identiteta i pripadnosti nekom kulturnom prostoru. U elemente nematerijalne kulturne baštine na prostoru Općine Šestanovac ubrajaju se različite poljoprivredne aktivnosti, umijeće gradnje suhozida, priprema hrane (soparnika), ganga i čuvanje Gospodinova groba u župi Radobilja (Katuni-Kreševo). U poljoprivredne se aktivnosti ubrajaju berba maslina i proizvodnja ulja, trganje grožđa i pravljenje vina, dok je tijekom prošlosti bilo puno više takvih aktivnosti, poput vršidbe žita na guvnu (Šestan, 2007.). Gradnja suhozida kulturno je naslijeđe čitave Primorske Hrvatske, pa i Sredozemlja u cjelini, sa svrhom označivanja i ograđivanja zemljišnih čestica te terasiranja padina. Od 2018. umijeće suhozidne gradnje nalazi se na UNESCO-ovoj listi zaštićene nematerijalne svjetske kulturne baštine (Ministarstvo kulture, 2018.). $\mathrm{Na}$ području općine prevladavaju uglavnom jednostavni tipovi suhozidne gradnje, ali mogu se naći i složeniji oblici, kao npr. suhozid s krunom. Ganga je tradicionalno skupno pjevanje narodnih pjesama u kojem jedan pjevač pjeva melodiju, a ostali ga prate. Opisuje se kao „grubo, nestandardno, netemperirano” petoglasje prapovijesnih korijena (Lorger, 2013.:501). Čuvanje Gospodinova groba običaj je stražarenja ispred lokaliteta koji predstavlja Kristov grob, za koji se pretpostavlja da je star više od 300 
godina. Pravo stražarenja imaju svi muškarci stariji od 16 godina (ili nakon što su primili sakrament potvrde) s prebivalištem u župi ili izvan nje, ako su podrijetlom iz naselja Katuna ili Kreševa (Turistička zajednica Općine Šestanovac, 2020.). Kao poznatiji primjer tradicionalnog jela može se navesti soparnik - tip pite od blitve koja se priprema ispod peke. Navedeni elementi materijalne i nematerijalne baštine zasad su slabo uključeni u turističku ponudu općine. Stoga je potrebno unaprijediti postojeće reklamiranje tih elemenata, približiti ih turistima, pripremati i nuditi domaću hranu na obiteljskim gospodarstvima i kućama za iznajmljivanje itd.

\subsection{Trenutačne značajke turizma u Općini Šestanovac}

Kretanje turističkog prometa u Općini Šestanovac može se pratiti od 2014., otkad se raspolaže s podacima o dolascima i noćenjima (Tablica 1). Međutim, izvjesno je da su turisti boravili na području Općine Šestanovac i ranije. Naime, već 2003. jedno se poljoprivredno gospodarstvo u Šestanovcu uz poljoprivredu bavilo turizmom, smještajem i drugim aktivnostima povezanima sa slobodnim vremenom (DZS, 2003.). Od 2014. pa do 2019., izuzev 2015., vidljiv je stalan porast broja turista i noćenja, odnosno povećanja turističkog prometa. Prevladavaju turisti iz stranih zemalja, najviše pojedinačno iz Njemačke i Poljske. Prosječan višegodišnji boravak turista kreće se od 8,4 do 9,6 dana, što je više od prosjeka RH, koji iznosi oko pet dana.

Tablica 1.

Kretanje broja turista i noćenja u Općini Šestanovac od 2014. do 2019. godine

\begin{tabular}{|c|c|c|c|c|c|c|}
\hline Godina & $\begin{array}{c}\text { Broj } \\
\text { domaćih } \\
\text { dolazaka }\end{array}$ & $\begin{array}{c}\text { Broj stranih } \\
\text { dolazaka }\end{array}$ & $\begin{array}{c}\text { UKUPNO } \\
\text { DOLASCI }\end{array}$ & $\begin{array}{c}\text { Broj } \\
\text { domaćih } \\
\text { noćenja }\end{array}$ & $\begin{array}{c}\text { Broj stranih } \\
\text { noćenja }\end{array}$ & $\begin{array}{c}\text { UKUPNO } \\
\text { NOĆENJA }\end{array}$ \\
\hline 2014. & 8 & 249 & 257 & 174 & 1991 & 2165 \\
\hline 2015. & 0 & 118 & 118 & 0 & 1137 & 1137 \\
\hline 2016. & 3 & 535 & 538 & 23 & 5087 & 5064 \\
\hline 2017. & 19 & 726 & 745 & 129 & 6708 & 6837 \\
\hline 2018. & 42 & 991 & 1033 & 251 & 8740 & 8991 \\
\hline 2019. & 136 & 1179 & 1315 & 445 & 10.490 & 10.935 \\
\hline
\end{tabular}

Izvor: izrađeno na temelju: Turistička zajednica Grada Omiša (2015., 2016.), DZS (2017., 2018., 2019., 2020.)

Godine 2019. na prostoru općine zabilježeno je 198 stalnih i 75 pomoćnih kreveta (DZS, 2020.:59), koje su bile u privatnom smještaju - kućama za odmor. Riječ je o starijim uređenim ili novoizgrađenim objektima visoke kvalitete koji nude raznoliku ponudu, čemu u prilog govori i činjenica da gotovo sve imaju i bazen. To je pojava karakteristična za prostor Dalmatinske zagore, Ravnih kotara, a posebno unutrašnjosti 
Istre (Vojnović, 2016.) (odnosno zaobalnih dijelova Primorske Hrvatske) kojom se želi privući i što dulje zadržati gosta. Krajem 2019. bilo je 18 takvih kuća na prostoru općine, dok Popisom stanovništva, domaćinstava i stanova iz 2011. nije zabilježena nijedna kuća odnosno stan za iznajmljivanje turistima. Istovremeno je 2011. zabilježen 231 stan za odmor i rekreaciju (8,8 \% ukupnog broja stanova) (DZS, 2011.).

Nekoliko je oblika turizma prisutno na prostoru općine u okviru ruralnog turizma ponajviše seoski turizam na obiteljskim poljoprivrednim gospodarstvima i pustolovni turizam, odnosno avanturizam. Krajem 2019. u općini su djelovala 72 obiteljska poljoprivredna gospodarstva na kojima su se uzgajale voćke (66 ha), masline (7,3 ha) i stoka (273 grla krupne i 689 grla sitne stoke) na 241 ha pašnjaka (Agencija za plaćanje u poljoprivredi, ribarstvu i ruralnom razvoju, 2020.). Iako je riječ o višestruko manjim vrijednostima nego sredinom 20. st. (tako je npr. Popisom poljoprivrede iz 1960. utvrđeno da je na istraživanom području bilo 1307 grla krupne i 3078 grla sitne stoke i da je korištena obradiva površina bila 769 ha) (Savezni zavod za statistiku, 1963.:218), dio stanovništva i dalje se bavi poljodjelstvom i stočarstvom. Dodatni je razlog tomu u novije vrijeme mogućnost dobivanja poticaja te pružanje usluga smještaja i pripreme hrane gostima, odnosno kombiniranje više djelatnosti na gospodarstvu. ${ }^{1}$

Uspješan primjer povezanosti poljoprivredne proizvodnje i turističke ponude ekološki je maslinik Jurin dvor u naselju Šestanovac. Na 7,5 hektara zemljišta podijeljenog u dvije parcele nalazi se 1800 stabala maslina koje su zasađene 2006. i 2007. godine. To gospodarstvo primjer je povezanosti agroturizma, ekoturizma i gastronomskog turizma. Ekoturizam oblik je turizma u kojem osviješteni gosti podupiru zaštitu okoliša na odredištu koje posjećuju, kao i kulturnu baštinu lokalne zajednice (Miljak, Bačić i Kitić, 2012.:327), a gastronomski turizam odnosi se na oblikovanje turističkog doživljaja koji proizlazi iz obrade, pripreme i konzumacije hrane (Drpić i Vukman, 2014.:63). $\mathrm{Na}$ imanju se proizvode mnogi ekološki proizvodi, kao maslinovo ulje, kreme, balzami, čajevi od lista masline, namazi od maslina, liker, konzervirane masline, različiti ukrasi od maslinova drveta itd. Dio proizvoda proda se odmah na imanju, a jedan dio prodaje se vodećim trgovačkim lancima u Republici Hrvatskoj. Nadalje, veliki dio izvozi se i na strana tržišta kao što je Njemačka i Austrija, a postoji zainteresiranost i iz Japana. Turisti koji posjete gospodarstvo sudjeluju u branju maslina i proizvodnji maslinova ulja, pa imaju priliku iz prve ruke iskusiti tradicionalni način života.

U naselju Grabovac postoji lovački muzej i zoološki vrt u privatnom vlasništvu. Lovačka zbirka ima više od 650 trofeja, a u sklopu obiteljskog imanja nalazi se i zoološki vrt $s$ više od 250 životinja. Posjetitelji mogu vidjeti nekoliko vrsta konja, jelena lopatara, srna, divokoza, muflona, vijetnamskih svinja, divljih svinja, peradi i mnoge vrste ptica. Na imanju se nalaze različite vrste starih alata, dvokolice i zaprežna kola, a cijela ponu-

${ }^{1}$ Da su neki OPG-ovi u tome vrlo uspješni, svjedoče i osvojene nagrade (Zadarski hr, 2020.). 
da upotpunjena je jahanjem i vožnjom kočijom, i to mustanzima, arapskim konjima i lipicancima.

Avanturizam ili pustolovni turizam oblik je turizma koji „spaja putovanje, sport i rekreaciju na otvorenom" (Uzelac, 2015.:2). Prema ATTA-i (Adventure Travel Trade Association), pustolovni turizam uključuje najmanje dva od ovih triju elemenata: fizičku aktivnost, odnosno korištenje fizičke snage, prirodni okoliš i upoznavanje različitih kultura (ATTA, 2020). Budući da sve više stanovništva živi u gradovima, ljudi u potrazi za uzbuđenjem, aktivnim odmorom i mogućim doživljajima „bježe u prirodu”. Najveći broj aktivnosti na kojima se temelji pustolovni turizam provodi se na rijeci Cetini, s obzirom na njezin brzi tok kroz kanjon, čiji se jedan dio nalazi na prostoru Općine Šestanovac. Riječ je o raftingu, kajakingu/kanuingu, kanjoningu (engl. cannonying) i riverboardingu/hydrospeedu. Kanjoning je aktivnost koja podrazumijeva prolazak kroz kanjon rijeke, ali i skakanje s vodopada, penjanje i spuštanje niz stijene, plivanje, prelazak brzaca itd. Riverboarding je aktivnost u kojoj osoba leži prsima na dasci i spušta se niz riječne brzace, a stopalima određuje smjer i brzinu plovidbe.

$\mathrm{Na}$ geomorfološki istaknutim rubnim dijelovima općine (posebno Biokovu) moguće je baviti se planinarenjem i trekingom. Treking je zahtjevniji tip pješačenja po terenu kojem nije moguće pristupiti uobičajenim prometnim sredstvima. Uređenjem biciklističkih staza različitih razina zahtjevnosti na području općine stvorili su se dobri preduvjeti za razvoj biciklističkoga turizma (cikloturizma). U okviru projekta MedPaths (Projekt MedPaths, 2019.), kojem je cilj bio razvoj strategije zaštite i revitalizacije zaobalja Splitsko-dalmatinske županije, na području Općine Šestanovac uređeno je pet biciklističkih staza. Brojni su seoski i šumski putovi koji se također mogu koristiti za bicikliranje jer na njima nema opasnosti (ili je vrlo mala) od motoriziranih vozila.

Avanturističke aktivnosti na prostoru Općine Šestanovac organizira nekoliko agencija koje sjedišta uglavnom imaju u priobalnom dijelu Splitsko-dalmatinske županije, a u svom poslovanju nastoje gostima ponuditi iskustva aktivnog odmora u zaobalju. Ukupan takav ostvareni promet nije velik, no očekuje se njegov daljnji porast.

\subsection{Anketno istraživanje}

U istraživanju je sudjelovalo 96 ispitanika (Tablica 2), gotovo podjednako muškaraca i žena. Približno $60 \%$ u dobi je od 25 do 54,9 godina, što se smatra primarnim radnim kontingentom. Najviše ispitanika ima završenu srednju školu, gotovo $80 \%$, dok ostatak čine oni koji imaju završenu osnovnu školi $(2,1 \%)$ i visokoobrazovani ispitanici (18,8 \%). Više od $52 \%$ ispitanika zaposleni su, 21,9 \% je nezaposlenih, a 15,6\% učenici su ili studenti. U Katunima je anketiran najveći broj stanovnika, a najmanje u Kreševu jer su to najveće i najmanje naseljene općine, odnosno primijenjeno je proporcionalno stratificirano uzorkovanje. 
Tablica 2.

Struktura uzorka prema spolu, dobi, obrazovnoj razini, ekonomskoj aktivnosti i naselju

\begin{tabular}{|c|c|c|c|}
\hline Varijabla & Modalitet & $\mathrm{N}$ & $\%$ \\
\hline \multirow{2}{*}{ Spol } & Žene & 49 & 51,0 \\
\hline & Muškarci & 47 & 49,0 \\
\hline \multirow{3}{*}{ Dob } & Od 15 do 24,9 godina & 31 & 32,2 \\
\hline & Od 25 do 54,9 godina & 57 & 59,4 \\
\hline & Više od 55 godina & 8 & 8,3 \\
\hline \multirow{3}{*}{ Obrazovna razina } & Osnovna škola & 2 & 2,1 \\
\hline & Srednja škola & 76 & 79,2 \\
\hline & Visoka škola (fakultet, magisterij i doktorat znanosti) & 18 & 18,8 \\
\hline \multirow{5}{*}{ Ekonomska aktivnost } & Zaposlen & 50 & 52,1 \\
\hline & Nezaposlen & 21 & 21,9 \\
\hline & Učenik / student & 15 & 15,6 \\
\hline & Umirovljenik & 4 & 4,2 \\
\hline & Ostalo & 6 & 6,2 \\
\hline \multirow{5}{*}{ Naselje } & Katuni & 27 & 28,1 \\
\hline & Kreševo & 11 & 11,5 \\
\hline & Grabovac & 19 & 19,8 \\
\hline & Šstanovac & 24 & 25,0 \\
\hline & Žeževica & 15 & 15,6 \\
\hline
\end{tabular}

Izvor: izrađeno na temelju rezultata anketnog istraživanja

Važna tvrdnja povezana s temom ovog rada bila je: Turizam može značajno pridonijeti budućem razvoju Opcíne Šestanovac. Više od 90 \% ispitanih uglavnom se ili u potpunosti slaže s tvrdnjom da bi turizam mogao biti pokretač razvoja u Općini Šestanovac (Slika 4). Gotovo da nema ispitanika koji se ne slaže s tom tvrdnjom. Očito je da se turizam, zbog značenja koje ima u hrvatskom gospodarstvu, posebno u Primorskoj Hrvatskoj, i u Općini Šestanovac percipira kao izrazito važna djelatnost koja može doprinijeti razvoju tog područja. 
Slika 4.

Mišljenje ispitanika o turizmu kao čimbeniku razvoja Općine Šestanovac

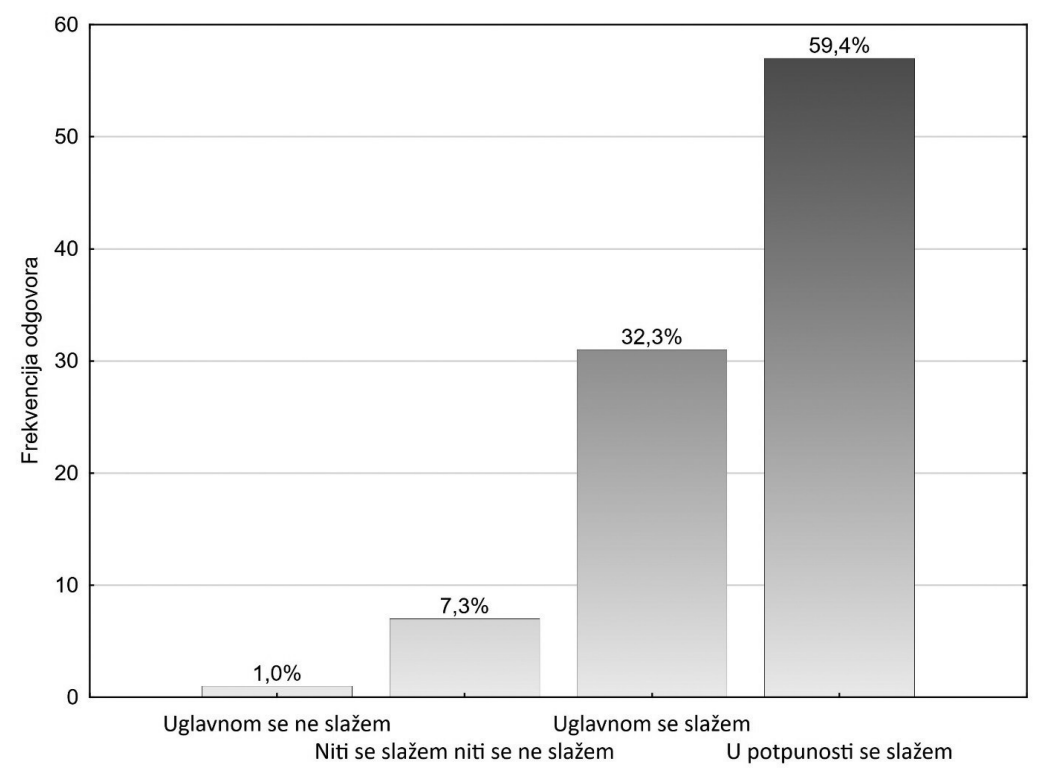

Izvor: izrađeno na temelju rezultata anketnog istraživanja

S obzirom na pitanje Čimbenici turističke atraktivnosti Općine Šestanovac, ispitanici su različito odgovarali (Slika 5). Očuvan okoliš od svih je čimbenika (prirodne osnove, odsutnosti buke i gužve, prometne povezanosti, smještajnih kapaciteta, graditeljske baštine, gastronomije i rekreacije) imao najveći postotak odgovora u potpunosti se sla$\check{z} e m$. Uz to se još ističu i prirodna osnova, odsutnost buke i gužve te donekle prometna povezanost. Ostale kategorije ocijenjene su nižim vrijednostima. Lokalno stanovništvo prepoznalo je okoliš i njegovu očuvanost kao glavne čimbenike razvoja turizma, što također nije iznenađujuće jer se u Hrvatskoj turizam uglavnom temelji na prirodnim značajkama, a ne na elementima kulturne baštine.

Iako je ispitano stanovništvo u prethodnim pitanjima u visokim postocima izrazilo pozitivno mišljenje o turizmu, na pitanje hoće li se oni baviti turizmom odgovori o slaganju i neslaganju uglavnom su ujednačeni (Slika 6). S jedne strane, stanovnici su vjerojatno svjesni rizika koji ulaganja i bavljenje turizmom nose i ne može se očekivati da će se starije stanovništvo ili budući umirovljenici početi baviti turizmom. Ali mlađe stanovništvo trebalo bi biti svjesno potrebe vlastitog angažmana kao važnog koraka u turističkom i ukupnom gospodarskom razvoju općine. Pokretanje obrta ne zahtijeva prevelika ulaganja (posebno paušalnog obrta), no, ovisno o vrsti obrta odnosno posla, nekad je potrebno biti stručno osposobljen ili položiti različite tečajeve koji mogu biti skuplji od pokretanja samog obrta. Ako je, primjerice, riječ o pustolovnom turizmu, valja imati i primjerenu opremu i sl., što zahtijeva dodatna ulaganja. Konačnu cijenu dodatno podiže i poslovni prostor, moguće koncesije itd. 
Slika 5.

Mišljenje ispitanika o čimbenicima turističkog razvoja Općine Šestanovac

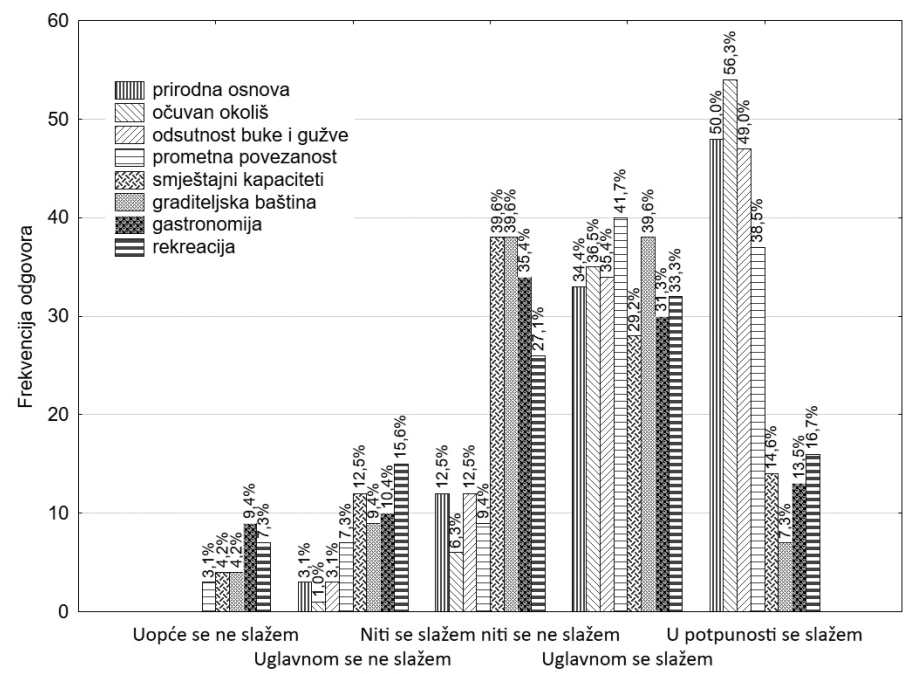

Izvor: izrađeno na temelju rezultata anketnog istraživanja

Slika 6.

Mišljenje ispitanika o bavljenju turizmom

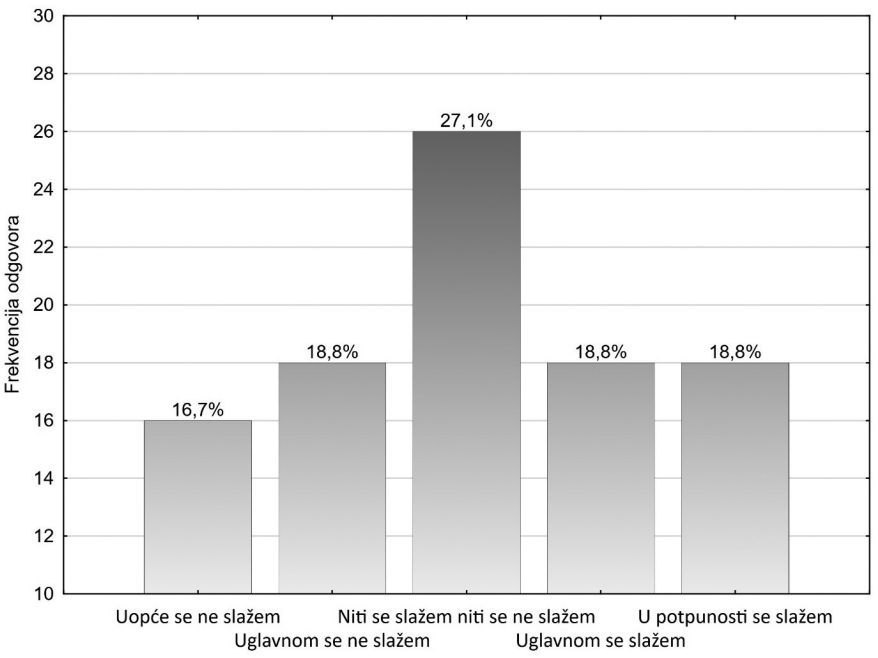

Izvor: izrađeno na temelju rezultata anketnog istraživanja

Tvrdnja čiji su odgovori prikazani na Slici 7. jedna je od postavljenih hipoteza. Gotovo $90 \%$ anketiranih smatra da bi jačanje turizma smanjilo iseljavanje. Razumljiv je takav udio odgovora jer kad bi postojali uvjeti rada i zapošljavanja na prostoru općine, zasigurno bi se stanovništvo manje iseljavalo. Nova radna mjesta u turizmu moguća su u turističkim agencijama, ugostiteljskim objektima i u OPG-ovima. 
Slika 7.

Mišljenje ispitanika o jačanju turizma i smanjenju iseljenja iz Općine Šestanovac

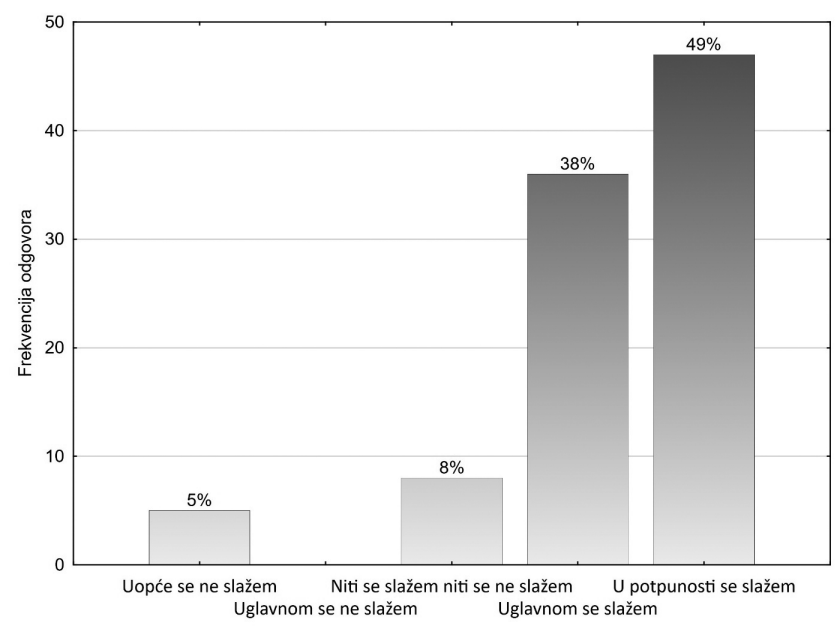

Izvor: izrađeno na temelju rezultata anketnog istraživanja

Prema mišljenju ispitanika o oblicima turizma koji se mogu razvijati na prostoru Općine Šestanovac, najbolje je ocijenjen seoski turizam, koji je ocjenom 5 vrednovalo više od polovice ispitanika (Slika 8). S izborom avanturizma i lovnog turizma slaže se nešto manji broj ispitanih. Općina je Šestanovac zaobalni ruralni prostor očuvanog okoliša u kojem upravo takvi oblici turizma imaju najveće razvojne mogućnosti. Ostaje upitno koliko ispitanici uopće poznaju ostale oblike turizma jer su u pitanju bila navedena samo tri oblika, i premda su imali tu mogućnost, sami nisu naveli nijedan drugi oblik.

Slika 8.

Mišljenje ispitanika o oblicima turizma koji se mogu razvijati u Općini Šestanovac

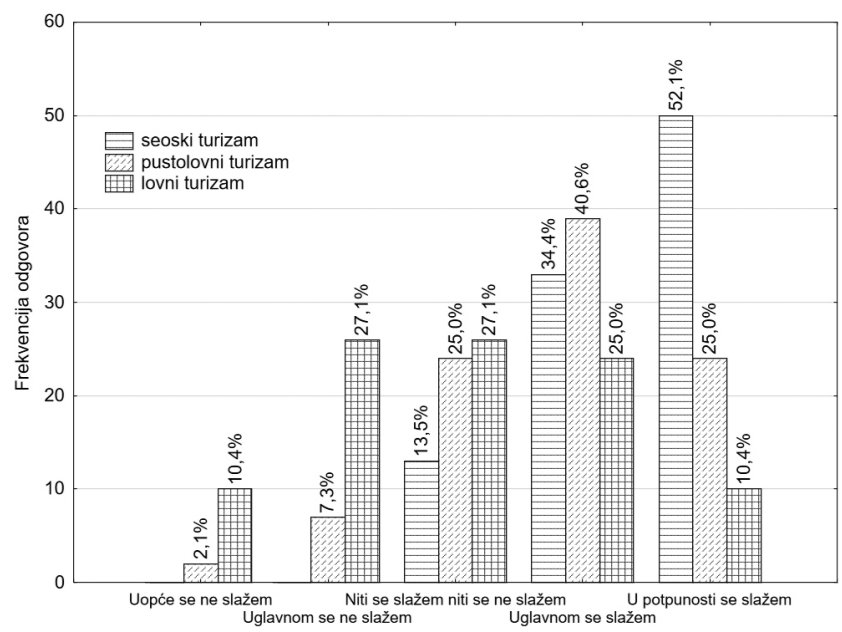

Izvor: izrađeno na temelju rezultata anketnog istraživanja 
Vrednovanje rijeke Cetine, uređenje biciklističkih staza, gradnja kuća za odmor i gastronomska ponuda prema mišljenju ispitanika najvažniji su konkretni koraci koje je potrebno poduzeti da bi se turizam značajnije razvio u Općini Šestanovac (Slika 9). Odgovori se zapravo nadovezuju na prethodno pitanje o oblicima turizma jer su navedene aktivnosti povezane sa seoskim i pustolovnim turizmom. Odgovor s kojim se ispitanici najmanje slažu ili se s njim uopće ne slažu u odnosu na ostale izgradnja je terena za golf i zabavnih parkova. Čini se da stanovništvo takve objekte smatra nepotrebnima ili smatra da imaju potencijalno negativne posljedice na okoliš.

Slika 9.

Mišljenje ispitanika o koracima turističkog razvoja Općine Šestanovac

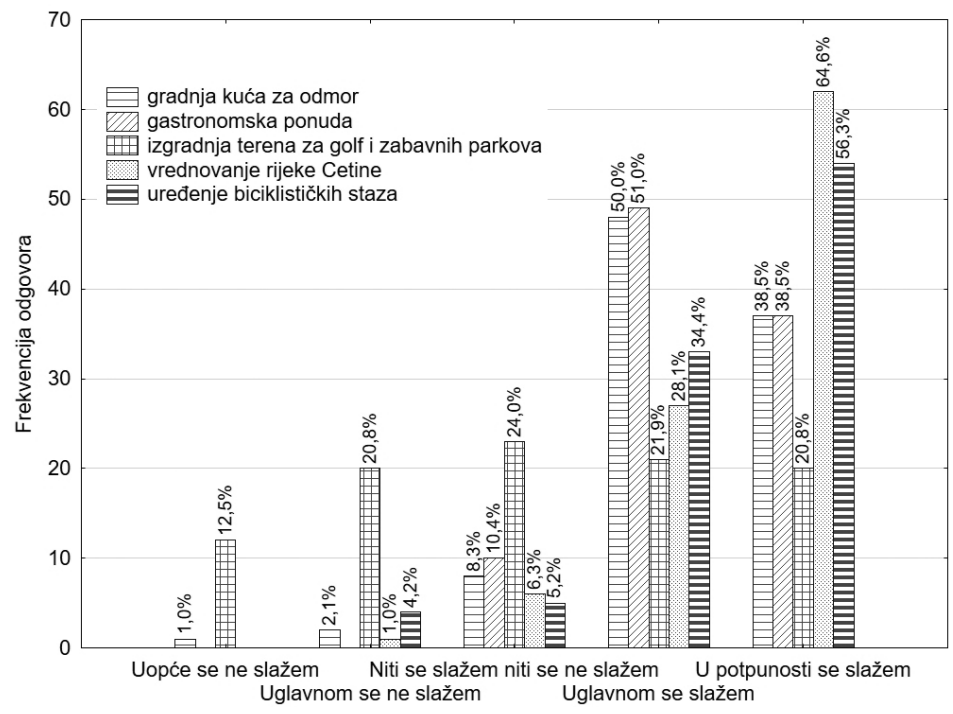

Izvor: izrađeno na temelju rezultata anketnog istraživanja

\subsubsection{Kvantitativne analize}

Za potrebe dodatne analize rezultata anketnog istraživanja provedene su dvije statističke metode, hi-kvadrat test i metoda korelacije. Prije toga izračunat je Crnobachov alfta-test pouzdanosti. On iznosi 0,78, što prema Tavakolu i Dennicku (2011.:54) nije savršen, ali je prihvatljiv rezultat. Rezultati hi-kvadrata gotovo su za sve tvrdnje visoki i statistički značajni, odnosno postoje statistički značajne razlike u odgovorima koje su dali ispitanici (Tablica 3). Razlog je tomu slaganje lokalnoga stanovništva (uglavnom i $u$ potpunosti se slažem) s postavljenim tvrdnjama. Samo u dvama pitanjima, o namjeri bavljenja turizmom i izgradnji terena za golf i zabavnih parkova kao čimbenika budućeg turističkog razvoja, nema statistički značajne razlike u odgovorima. U cjelini anketno istraživanje pokazalo je da stanovništvo smatra kako Općina Šestanovac ima brojne mogućnosti za razvoj turizma i da budući razvoj treba poticati s različitih 
aspekata. Prema njihovu mišljenju, najznačajniji je čimbenik turističke atraktivnosti općine očuvan okoliš i graditeljska baština. Smatraju da se budući razvoj treba ostvariti vrednovanjem rijeke Cetine i gradnjom kuća, dakle onih resursa kojima se u određenoj mjeri u općini već koristi.

Tablica 3.

Rezultati hi-kvadrat testa analiziranih varijabli

\begin{tabular}{|c|c|c|}
\hline Varijabla & $\chi^{2}$ & $\begin{array}{l}\text { stupnjevi } \\
\text { slobode }\end{array}$ \\
\hline Zadovoljstvo kvalitetom života & $25,71^{*}$ & 4 \\
\hline Treba težiti održivom razvitku 0pćine Šestanovac & $71,58^{*}$ & 4 \\
\hline Poticanje poljoprivrede općenito & $83,27^{*}$ & 4 \\
\hline Turizam može pridonijeti razvoju općine & $81,50^{*}$ & 4 \\
\hline Preduvjet razvoja turizma je mlado stanovništvo & $79,52^{*}$ & 4 \\
\hline Namjera bavljenja turizmom & 3,17 & 4 \\
\hline Jačanje turizma smanjit će iseljavanje & $53,75^{*}$ & 3 \\
\hline Čimbenici turističke atraktivnosti općine: prirodne značajke & $51,75^{*}$ & 3 \\
\hline Čimbenici turističke atraktivnosti općine: očuvan okoliš & $78,08^{*}$ & 3 \\
\hline Čimbenici turističke atraktivnosti općine: odsutnost buke i gužve & $50,58^{*}$ & 3 \\
\hline Čimbenici turističke atraktivnosti općine: prometna povezanost & $65,88^{*}$ & 4 \\
\hline Čimbenici turističke atraktivnosti općine: smještajni kapaciteti & $38,58^{*}$ & 4 \\
\hline Čimbenici turističke atraktivnosti općine: graditeljska baština & $62,02^{*}$ & 4 \\
\hline Čimbenici turističke atraktivnosti općine: gastronomija & $29,31^{*}$ & 4 \\
\hline Čimbenici turističke atraktivnosti općine: mogućnost rekreacije & $20,15^{*}$ & 4 \\
\hline Povoljne uvjete razvoja ima seoski turizam & $45,98^{*}$ & 4 \\
\hline Povoljne uvjete razvoja ima pustolovni turizam & $21,44^{*}$ & 4 \\
\hline Povoljne uvjete razvoja ima lovni turizam & $14,83^{*}$ & 4 \\
\hline Turizam se treba razvijati gradnjom kuća & $98,90^{*}$ & 4 \\
\hline Turizam se treba razvijati gastronomskom ponudom & $24,94^{*}$ & 2 \\
\hline Turizam se treba razvijati uređenjem biciklističkih staza & $72,58^{*}$ & 3 \\
\hline Turizam se treba razvijati vrednovanjem rijeke Cetine & $96,08^{*}$ & 3 \\
\hline Turizam se treba razvijati izgradnjom terena za golf i zabavnih parkova & 3,69 & 4 \\
\hline
\end{tabular}

${ }^{*} \mathrm{p}<0,05$

Izvor: izračunato na temelju rezultata anketnog istraživanja

Korelacijom se istražio utjecaj dobi ili stupnja obrazovanja na odgovore o različitim vidovima razvoja Općine Šestanovac. Korišten je Spearmanov koeficijent korelacije jer su sve zavisne varijable izražene na ordinalnoj ljestvici. Korelacija (povezanost) statistički je značajna tek kod polovine postavljenih varijabli, i to kad su u korelaciji s dobi (Tablica 4). Očito je da što je stanovništvo starije, to je manje njihovo slaganje s tvrdnjama o preseljenju iz općine, turizmu kao čimbeniku razvoja općine i bavljenju turiz- 
mom, za razliku od mlađeg stanovništva, koje se s tim tvrdnjama slaže u većoj mjeri. Zbog toga je i korelacija negativna. Jedina statistički značajna i pozitivna korelacija proizlazi iz zadovoljstva životom u općini, a koja raste kako raste dob ispitanika. Dakle, starije stanovništvo manje je „zahtjevno“ - većinom su to zaposleni ljudi koji nemaju ostale potrebe poput mlađeg stanovništva (zabava, kulturni sadržaji i sl.). Stoga ne čudi da je starije stanovništvo zadovoljnije kvalitetom života u općini. Međutim, koeficijenti korelacije ni u jednom slučaju nisu veći od 0,34 , pa je zaključak da dob nije ni jedini ni dominantni čimbenik koji utječe na promišljanje o razvoju općine.

S druge strane, stupanj obrazovanja ne pokazuje statistički značajnu korelaciju s odabranim pitanjima ni u jednom slučaju. Dakle, različite razine obrazovanja ispitanika ne utječu na različitost mišljenja o pojedinim varijablama, odnosno tvrdnjama. Očito je da cjelokupno stanovništvo s obzirom na razinu obrazovanja misli otprilike slično ili isto, tj. slaže se u temeljnim pitanjima povezanima s egzistencijom stanovništva općine.

Tablica 4.

Spearmanov koeficijent korelacije između analiziranih varijabli

\begin{tabular}{|l|c|c|}
\hline & Dob & $\begin{array}{c}\text { Stupanj } \\
\text { obrazovanja }\end{array}$ \\
\hline Zadovoljstvo kvalitetom života u Općini Šestanovac & $0,26^{*}$ & $-0,07$ \\
\hline Preseljenje zbog posla ili kvalitetnijeg života & $-0,34^{*}$ & 0,09 \\
\hline Poticanje poljoprivrede općenito & 0,08 & 0,08 \\
\hline Turizam može doprinijeti razvoju Općine Šestanovac & $-0,28^{*}$ & $-0,13$ \\
\hline Povoljne uvjete razvoja ima ruralni turizam & 0,09 & $-0,07$ \\
\hline Namjera bavljenja turizmom & $-0,23^{*}$ & $-0,07$ \\
\hline Preduvjet razvoja turizma je mlado stanovništvo & 0,04 & $-0,16$ \\
\hline Jačanje turizma bi smanjilo iseljavanje & 0,12 & $-0,09$ \\
\hline
\end{tabular}

${ }^{*} \mathrm{p}<0,05$

Izvor: izračunato na temelju rezultata anketnog istraživanja

\section{Zaključak}

U radu je istražena problematika razvoja ruralnog turizma na području Općine Šestanovac. Problemi koji opterećuju općinu, poput gubitka stanovništva, manjka radnih mjesta i sl., uvjetovali su promišljanje o mogućnostima revitalizacije općine. S obzirom na geografski položaj Općine Šestanovac, prometnu povezanost, prirodne značajke, kulturu življenja i ostalo, turizam se nameće kao jedna od mogućnosti unaprjeđenja gospodarske slike i kvalitete života lokalnog stanovništva. Jasno je da se ne može govoriti o velikom broju potencijalnih gostiju i masovnom turizmu, nego o ruralnom turizmu. U Općini Šestanovac bi mogli bi razvijati seoski turizam, gastronomski turi- 
zam, pojedini oblici pustolovnog turizma (temeljen na raftingu, trekingu, kanjoningu i sl.) te biciklizam. Zbog toga treba unaprjeđivati turističku ponudu i poticati oblike turizma koji mogu dovesti do postupnog gospodarskog oporavka općine.

$\mathrm{Na}$ temelju dobivenih rezultata moguće je prihvatiti sve tri hipoteze. Prva hipoteza glasi Najpovoljnije uvjete razvoja u Općini Šestanovac ima seoski turizam. Naime, uzimajući u obzir prirodne i društvene značajke općine, dosadašnji razvoj turizma te stavove ispitanih o ovoj tvrdnji, jasno je da seoski turizam ima najbolje preduvjete razvoja. Lokalno stanovništvo smatra da turizam može značajno pridonijeti razvoju Općine Šestanovac druga je hipoteza i s njom se uglavnom i u potpunosti slaže gotovo $92 \%$ ispitanika. I treća hipoteza, Ako bi im bavljenje turizmom pružalo egzistenciju, mlade generacije ne bi emigrirale iz općine, pozitivno je prihvaćena, na što ukazuje podatak da se s njom slaže $87 \%$ ispitanika. Razumljivo je da su to mišljenja i stavovi ispitanika, a da realizacija turističke aktivnosti (u većem obujmu nego danas) ovisi o nizu različitih čimbenika. Zbog toga ovaj rad predstavlja iskorak u poznavanju te problematike na prostoru Općine Šestanovac i daje neke smjernice mogućeg budućeg razvoja turizma.

\section{Literatura i izvori}

1. Agencija za plaćanje u poljoprivredi, ribarstvu i ruralnom razvoju (2020). Upisnik poljoprivrednika 2019. Zagreb: Agencija za plaćanje u poljoprivredi, ribarstvu i ruralnom razvoju. https://www.apprrr.hr/. (Pregledano 14. veljače 2020.)

2. Alaupović Gjeldum, D. (2007). Seoska graditeljska baština, u: Kusin, V. (Ur.). Dalmatinska zagora - Nepoznata zemlja. Zagreb: Klovićevi dvori, 429-451.

3. Anketno istraživanje, provedeno u listopadu 2017.

4. Adventure Travel Trade Association (2020). About us. https://www.adventuretravel.biz/about/. (Pregledano 2. ožujka 2020.)

5. Bekavac, J. (2011). Utjecaj turizma na preobrazbu Omiško-poljičkog kraja. diplomski rad. Zagreb: Sveučilište u Zagrebu, Prirodoslovno-matematički fakultet, Geografski odsjek.

6. Božić Juras, A. (2019). Mogućnost razvoja ruralnog turizma na prostoru Dalmatinske zagore. završni rad. Zagreb: Sveučilište u Zagrebu, Ekonomski fakultet.

7. Buble, S. (2007). Kamen u tradicijskoj arhitekturi, u: Kusin, V. (Ur.). Dalmatinska zagora - Nepoznata zemlja. Zagreb: Klovićevi dvori, 451-463.

8. Carević, I. (2011). Problemi i mogućnosti održivog razvoja Omiške zagore na primjeru Općine Šestanovac, u: Matas, M. i Faričić, J. (Ur.). Zagora izmedu stočarsko-ratarske tradicije te procesa litoralizacije i globalizacije. Zadar, Zagreb, Split: Sveučilište u Zadru, Kulturni sabor Zagore, Ogranak Matice hrvatske Split, 209-222.

9. Ćubelić, I. (2018). Potencijali turizma u revitalizaciji ruralnih područja Dalmatinske zagore. završni rad. Split: Sveučilište u Splitu, Ekonomski fakultet.

10. Demonja, D. i Ružić, P. (2010). Ruralni turizam u Hrvatskoj s hrvatskim primjerima dobre prakse i europskim iskustvima. Samobor: Meridijani. 
11. Demonja, D. (2014). The Overview and Analysis of the State of Rural Tourism in Croatia. Sociologija i prostor, 52 (1): 69-90.

12. Drpić, K. i Vukman, K. (2014). Gastronomija kao važan dio turističke ponude u Hrvatskoj. Praktični menadžment: stručni časopis za teoriju i praksu menadžmenta, 5 (1): 62-67.

13. Državni hidrometeorološki zavod (2017). Podaci za meteorološku postaju Šstanovac (oborine, temperatura), 1981. - 2010. Zagreb: Državni hidrometeorološki zavod. Ustupljeno 6. listopada 2017.

14. Državni zavod za statistiku (2003). Popis poljoprivrede 2003., Broj poljoprivrednih kućanstava s ostalima dopunskim djelatnostima na posjedu. Zagreb: Državni zavod za statistiku. https://www.dzs.hr/. (Pregledano 13. veljače 2020.)

15. Državni zavod za statistiku (2011). Stanovi prema načinu korištenja 2011. Zagreb: Državni zavod za statistiku. https://www.dzs.hr/. (Pregledano 12. veljače 2020.)

16. Državni zavod za statistiku (2011). Zaposleni prema područjima djelatnosti, starosti $i$ spolu, popis 2011. Zagreb: Državni zavod za statistiku. https://www.dzs. hrl. (Pregledano 12. veljače 2020.)

17. Državni zavod za statistiku (2017, 2018, 2019, 2020). Turizam u 2016., Statistička izvješća 1594, Turizam u 2017., Statistička izvješća 1616, Turizam u 2018., Statistička izvješća 1639., Turizam u 2019., Statistička izvješ́a 1661. Zagreb: Državni zavod za statistiku. https://www.dzs.hr/. (Pregledano 13. veljače 2020. i 30. prosinca 2020.)

18. Državni zavod za statistiku (2019). Procjena stanovništva prema spolu, po gradovimalopćinama, 31. 12. 2018. Zagreb: Državni zavod za statistiku. https:// www.dzs.hr/. (Pregledano 12. veljače 2020.)

19. Državni zavod za statistiku (2020). Naselja i stanovništvo Republike Hrvatske 1857. - 2001. Zagreb: Državni zavod za statistiku. https://www.dzs.hr/. (Pregledano 11. veljače 2020.)

20. ESRI (2012). ArcMap, verzija 10.1. Redmond.

21. Grcić, T. (2012). Mogućnosti turističke valorizacije Dalmatinske zagore. završni rad. Zagreb: Sveučilište u Zagrebu, Prirodoslovno-matematički fakultet, Geografski odsjek.

22. Grgić, I.; Hadelan, L.; Krznar, S.; Zrakić, M. (2017). Could rural tourism revitalize rural areas in Croatia?. Agroeconomia Croatiaca, 7 (1): 98-108.

23. Košak, M. and Lugomer, K. (2015). The role of agrotourism in tourist season extension in Littoral Croatia. Hrvatski geografski glasnik, 77 (2): 141-168.

24. Kušen, E. (2002). Turistička atrakcijska osnova. Zagreb: Institut za turizam.

25. Kušen, E. (2003). Uređenje, razvoj i obnova hrvatskog ruralnog prostora. Sociologija i prostor, 41 (1-2): 29-45.

26. Lorger, S. (2013). Ganga: Priprosto (polifono) skupno pjevanje. Anali Zavoda za povijesne znanosti Hrvatske akademije znanosti i umjetnosti u Dubrovniku, 51 (2): 501-539.

27. Lukić, A. (2012). Mozaik izvan grada-tipologija ruralnih i urbaniziranih naselja Hrvatske. Samobor: Meridijani. 
28. Lukić, A. (2014). Tourism, Farm Diversification and Plurality of Rurality: Case Study of Croatia. European Countryside, 5 (4): 356-376.

29. Lukić, A.; Radeljak Kaufmann, P. and Pejnović, D. (2016). Quo Vadis Rural Croatia: Scenarios for Future Development of the Croatian Countryside. poster prezentacija. http://www.croruris.info/wpcontent/uploads/2016/09/Lukic Kaufmann Pejnovic_Rumunjska_poster.pdf. (Pregledano 18. veljače 2020.)

30. Malenica, N. (2016). Prirodno kretanje stanovništva Dalmatinske zagore - primjer izabranih općina Lovreć, Šestanovac i Zagvozd. završni rad. Zagreb: Sveučilište u Zagrebu, Prirodoslovno-matematički fakultet, Geografski odsjek.

31. Miljak, T.; Bačić, L. i Kitić, M. (2012). Ekoturizam kao poticaj razvoja poduzetništva u turizmu na primjeru Republike Hrvatske. Učenje za poduzetništvo, 2 (2): 323-331.

32. Ministarstvo kulture (2018). Medimurska popevka, tradicijski napjev Mecimurja i Umijeće suhozidne gradnje upisani na UNESCO-ov Reprezentativni popis nematerijalne baštine čovječanstva. Zagreb: Ministarstvo kulture. https://www.minkulture.hr/default.aspx?id=21505. (Pregledano 18. veljače 2020.)

33. Ministarstvo kulture (2020). Registar kulturnih dobara Republike Hrvatske. Zagreb: Ministarstvo kulture. https://www. min-kulture.hr/default.aspx?id=6212. (Pregledano 18. veljače 2020.)

34. Ministarstvo regionalnog razvoja i fondova Europske unije (2018). Indeks razvijenosti. Zagreb: Ministarstvo regionalnog razvoja i fondova Europske unije, https://razvoj.gov.hr/o-ministarstvu/regionalni-razvoj/indeks-razvijenosti/112. (Pregledano 15. veljače 2020.)

35. Ministarstvo turizma (2019). Turizam u brojkama u 2018. Zagreb: Ministarstvo turizma.

36. Natura 2000 (2019). Informacijski sustav zaštite prirode. http://www.bioportal. hr/gis/. (Pregledano 1. ožujka 2020.)

37. Nejašmić, I. i Štambuk, M (2003). Demografsko stanje i procesi u neurbanim naseljima Republike Hrvatske. Društvena istraživanja, 65-66: 469-493.

38. Nejašmić, Š. (2015). Ruralni turizam kao čimbenik razvoja Omiške zagore. završni rad. Zagreb: Sveučilište u Zagrebu, Prirodoslovno-matematički fakultet, Geografski odsjek.

39. Pastuović, J. (2016). Upravljanje turističkom destinacijom s osvrtom na ruralni turizam Dalmatinske zagore. završni rad. Šibenik: Veleučilište u Šibeniku.

40. Projekt MedPaths (2020). PROJEKT „MedPaths" The Snapshot of Mediterranean Hinterlands Richness. http://www.eu-medpaths.com/hr-hr/projekt.aspx. (Pregledano 2. ožujka 2020.)

41. Radeljak Kaufmann P. (2016). Integrating factor analysis and the Delphi method in scenario development: A case study of Dalmatia, Croatia. Applied Geography, 71: 56-68.

42. Rajković Iveta, M. i Horvatin, T. (2017). Suvremeno iseljavanje iz Hrvatske u Irsku s posebnim osvrtom na mlade iz Slavonije. Migracijske i etničke teme, 33 (3): 247-274. 
43. Ružić, P. i Demonja, D. (2013). Prirodna i antropogena osnova turizma Hrvatske. Sociologija i prostor, 51 (1): 45-65.

44. Savezni zavod za statistiku (1963). Popis poljoprivrede 1960., Knjiga 1, Osnovni podaci individualnih gazdinstava po naseljima. Beograd: Savezni zavod za statistiku.

45. Središnji registar prostornih jedinica (SRPJ) RH (2016). Zagreb: Državna geodetska uprava.

46. Svržnjak, K.; Kantar, S.; Jerčinović, S.; Gajdić, D. (2014). Mogućnosti razvoja ekoturizma u Koprivničko-križevačkoj županiji. Križevci: Visoko gospodarsko učilište u Križevcima, Hungary-Croatia IPA Cross-border Co-operation Programme, ECOTOP.

47. Šegota, T. i Filipčić, A. (2003). Köppenova podjela klima i hrvatsko nazivlje. Geoadria, 8 (1): 17-37.

48. Šestan, I. (2007). Tradicijsko gospodarstvo, poljodjelstvo, vinogradarstvo i stočarstvo, u: Kusin, V. (Ur.). Dalmatinska zagora - Nepoznata zemlja. Zagreb: Klovićevi dvori, 463-479.

49. Tavakol, M. and Dennick R. (2011). Making sense of Cronbach's alpha. International Journal of Medical Education, editorial, 2: 53-55.

50. Terensko istraživanje, provedeno u prosincu 2019.

51. Todorić, I. (2017). Potencijali turističke valorizacije Dalmatinske zagore. završni rad. Split: Sveučilište u Splitu, Ekonomski fakultet.

52. Tomić, F. (2014). Stanje i mjere unapređenja hrvatske poljoprivrede u svjetlu pristupa Europskoj uniji. Civitas Crisiensis, 1: 129-142.

53. Turistička zajednica Grada Omiša (2015., 2016). Broj turista i noćenja 2014. i 2015. u Šestanovcu. Omiš: Turistička zajednica Grada Omiša.

54. Turistička zajednica Općine Šestanovac (2020). Nematerijalna kulturna baština Općine Šestanovac. Šestanovac: Turistička zajednica Općine Šestanovac. https:// sestanovac.com/hr/sto-vidjeti/nematerijalna-kulturna-bastina-opcine-sestanovac. (Pregledano 26. veljače 2020.)

55. TIBCO Software Inc. (2017). Statistica, verzija 13.3. Palo Alto.

56. Uzelac, N. (2015). Marketing pustolovnog turizma u Hrvatskoj. Zagreb: Ekonomski fakultet, Katedra za turizam.

57. Vojnović, N. (2011). Stanje i mogućnosti razvoja turizma u unutrašnjosti Splitsko-dalmatinske županije, u: Matas, M. i Faričić, J. (Ur.). Zagora između stočarsko-ratarske tradicije te procesa litoralizacije i globalizacije. Zadar, Zagreb, Split: Sveučilište u Zadru, Kulturni sabor Zagore, Ogranak Matice hrvatske Split. 209-222.

58. Vojnović, N. (2016). Održivi turizam unutrašnje Istre. Pula: Sveučilište Jurja Dobrile.

59. Zadarski hr. (2020). Dvori iz Šestanovca šampioni seoskog turizma. https://zadarski.slobodnadalmacija.hr/zadar/regional/dvori-iz-sestanovca-sampioni-seoskogturizma-stranci-su-ludi-za-nasim-kamenjarom-i-kruhom-ispod-peke-zaviriteu-ovih-15-000-kvadrata-mira-i-tisine-1004723. (Pregledano 26. veljače 2020.) 


\title{
Contribution to the Study of the Development and Significance of Rural
} Tourism in Šestanovac Municipality

\author{
Nediljko Ralica \\ Statim Ltd., Split, Croatia \\ e-mail: nenor14@gmail.com \\ Ante Blaće \\ University of Zadar, Department of Geography, Croatia \\ e-mail:anblace@unizd.hr
}

\begin{abstract}
This paper examined the possibilities of tourism development in the Šestanovac Municipality, a rural area of the Omiš part of the Dalmatinska Zagora region. The elements of natural and cultural heritage that can be valorized in tourism were evaluated and the current state of tourism in the municipality was analyzed based on the statistical data and fieldwork. A survey was also conducted to find out the opinion of the local population on various aspects of tourism development in the Šestanovac Municipality. The results indicate that the number of tourists visiting Šestanovac is not large, but it is continuously increasing. So far, the most developed form of tourism is rural tourism on small family farms and in holiday homes and adventure tourism that takes place in the Cetina River Canyon, on Biokovo Mountain, and on cycling trails. The tangible and intangible cultural heritage is not yet sufficiently valorized and should be included more in the tourist offer. The local population believes that tourism can play a big role in the future economic development of the municipality and generally positively perceives everything that is happening concerning tourism in Šestanovac.
\end{abstract}

Key words: tourism, Šestanovac Municipality, rural tourism, adventure tourism, natural and cultural heritage. 